\title{
VARIASI GENETIK IKAN JELAWAT HASIL BUDIDAYA DAN TANGKAPAN ALAM DI PONTIANAK DENGAN MENGGUNAKAN MARKER DNA-RAPD (RANDOM AMPLIFIED POLYMORPHISM DNA)
}

\author{
Estu Nugroho*), Sri Sundari*), dan Nunung Nur Rachman**) \\ *) Balai Riset Perikanan Budidaya Air Tawar \\ Jl. Raya Sempur No. 1, Bogor 16154 \\ E-mail: brpbat@yahoo.com \\ **) Kepala Unit Pembenihan Ikan Sentral (UPIS), Dinas Perikanan Provinsi Kalimantan Barat
}

\begin{abstract}
ABSTRAK
Evaluasi variasi genetik ikan jelawat yang dikoleksi dari alam dan kegiatan budidaya telah dilakukan dengan menggunakan marker RAPD. Sampel berupa sirip dari kedua stok tersebut diekstraksi dan diamplifikasi dengan menggunakan primer OPA 1-20. Secara genetik tidak terdapat perbedaan yang nyata antara kedua stok ikan jelawat yang diuji. Tingkat heterozigositas berdasarkan 2 primer RAPD (OPA 2 dan OPA 3) adalah 0,1450 terdapat pada ikan jelawat hasil tangkapan alam sedangkan pada ikan jelawat hasil budidaya adalah 0,1350. Jarak genetik Nei antara keduanya adalah 0,3881.
\end{abstract}

\section{KATAKUNCl: variasi genetik, jelawat, RAPD}

\section{Pendahuluan}

Ikan jelawat termasuk salah satu komoditas ekonomis penting di daerah Kalimantan Barat, khususnya di Pontianak. Perkembangan budidaya ikan tersebut masih dalam fase awal. Masyarakat umumnya mendapatkan ikan jelawat dari hasil tangkapan alam.

Penangkapan yang tidak terkendali sedangkan budidayanya masih belum banyak berkembang dapat menjadi penyebab punahnya sumberdaya ikan di perairan alam. Unit Pembenihan Ikan Sentral (UPIS) sebagai salah satu unit teknis Dinas Kelautan dan Perikanan merupakan salah satu institusi yang mempunyai peranan penting dalam mendukung perkembangan budidaya ikan jelawat. Salah satunya dengan memproduksi benih yang bermutu.

Langkah awal yang perlu dilakukan adalah dengan mengkoleksi induk-induk jelawat dari alam untuk digunakan sebagai penghasil benih ikan budidaya. Pengetahuan tentang asal-usul ikan serta variasi genetik stok induk yang dipunyai merupakan faktor penting yang dibutuhkan untuk penentuan program pemuliaan yang tepat mengingat ikan jelawat dikenal cukup lambat pertumbuhannya. Penelahan data dasar genetik ini dapat digunakan untuk mengevaluasi fitness individu jangka pendek dan sintasan suatu populasi untuk jangka panjang (Ferguson et al., 1995).

\section{BAHAN DAN METODE}

\section{Ikan Uji}

Ikan uji yang digunakan dalam penelitian ini adalah ikan jelawat hasil budidaya tahun 2006 dan ikan hasil tangkapan alam di Daerah Sintang tahun 2008. Masingmasing populasi terdiri atas 10 sampel.

\section{Ekstraksi DNA}

DNA ikan diekstraksi dari potongan sirip dengan menggunakan metode phenol-chloroform, sebagai berikut; 5-10 mg potongan sirip ikan dimasukkan kedalam tabung $1,5 \mathrm{~mL}$ yang telah berisi $500 \mu \mathrm{L}$ larutan TNES Urea. Kemudian ditambahkan $10 \mu \mathrm{g} / \mathrm{mL}$ Protein Kinase dan diinkubasikan pada suhu $37^{\circ} \mathrm{C}$ selama 12 jam.

Sebanyak $500 \mu \mathrm{L}$ larutan phenol-chloroform ditambahkan ke dalam tabung di atas untuk selanjutnya di vortex selama 1 menit dan disentrifuse pada kecepatan 10.000 rpm selama 10 menit. Lapisan supernatannya diambil dan dimasukkan ke dalam tabung baru, dan ditambahkan $600 \mu \mathrm{L}$ larutan propanol dan divortex sampai terlihat endapan putih.

DNA diendapkan dengan cara mensentrifus campuran tersebut pada kecepatan 10.000 rpm selama 10 menit, kemudian larutan di atasnya dibuang dan DNA dikeringkan pada suhu ruangan. Kemudian dilarutkan kembali dalam 50-100 $\mu$ L Tris-EDTA (TE) buffer dan disimpan dalam suhu $4^{\circ} \mathrm{C}$ sebelum digunakan pada tahap selanjutnya.

\section{RAPD (Random Amplified Polymorphism DNA)}

Penyeleksian terhadap 20 primer (OPA1-20) dilakukan untuk mendapatkan primer yang mempunyai produk amplifikasi yang sesuai dengan DNA ikan jelawat. 
Pengamplifikasian dilakukan menggunakan metode Polymerase Chain Reaction (PCR) dengan komposisi reaksi yang terdiri: $10 \mu \mathrm{g}, 10 \mathrm{pmol}$ setiap primer dan "pure taq DNA" (Promega) dengan total volume keseluruhannya 25 $\mu \mathrm{L}$. Siklus PCR yang digunakan dalam amplifikasi adalah satu siklus denaturasi pada suhu $94^{\circ} \mathrm{C}$ selama 2 menit, 45 siklus penggandaan yang terdiri atas $94^{\circ} \mathrm{C}$ selama 1 menit, $36^{\circ} \mathrm{C}$ selama 1 menit dan $72^{\circ} \mathrm{C}$ selama 2,5 menit. Selanjutnya satu siklus terakhir pada suhu $72^{\circ} \mathrm{C}$ selama 10 menit.

Hasil amplifikasi kemudian dipisahkan secara elektroforesis dengan menggunakan gel agarose 2\%3\% dalam Tris-Boric-EDTA (TBE) buffer dan diamati dengan illuminator (UV) serta dicetak gambarnya dengan polaroid.

\section{Analisis Data}

Untuk mengevaluasi variasi DNA antar ras ikan gurame dilakukan dengan menggunakan analisis molekuler varians (AMOVA) dan Fst dalam program TFPGA (Miller, 1997). Kekerabatan antar ras dianalisis dengan menggunakan Jarak Genetik, Nei (1972).

\section{HASIL DAN BAHASAN}

Dua dari 20 primer yang diuji mempunyai hasil ampifikasi yang cukup baik yaitu OPA-2 dan 3. Jumlah total pita yang diamati dari dua primer tersebut adalah 20 buah dengan panjang mulai 300 bp hingga 1.200 bp. Salah satu hasil amplifikasi dengan primer OPA-2 dan 3 terlihat pada Gambar 1.

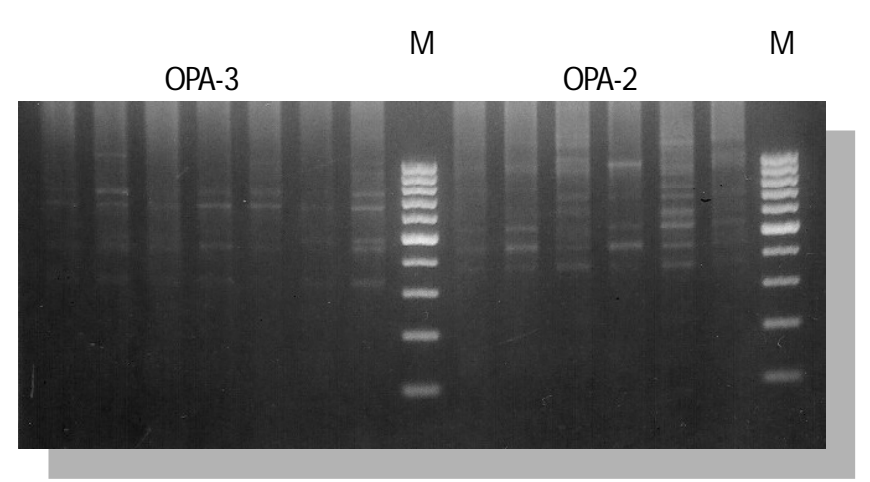

Gambar 1. Fragmen hasil amplifikasi RAPD dengan menggunakan primer OPA-2 dan OPA-3. $\mathrm{M}=$ Marker

Tingkat variasi heterozigositas dipengaruhi oleh asal usul ikan jelawat. Secara umum ikan jelawat yang diteliti mempunyai tingkat keragaman yang sedang dengan nilai heterozigositas rata-rata 0,1378 , dengan nilai tertinggi terdapat pada ikan jelawat alam $(0,1450)$ kemudian ikan jelawat budidaya $(0,1305)$ (Tabel 1$)$. Nilai ini sedikit lebih tinggi dibandingkan ikan air tawar lainnya. Umumnya, variasi genetik pada ikan air tawar tergolong cukup rendah sebagai akibat keterbatasan migrasi secara alami, seperti misalnya pada ikan kancra (Nugroho et al., 2006).

Lebih tingginya nilai ikan jelawat dari alam dibandingkan ikan budidaya menunjukkan bahwa telah terjadi "inbreeding depression" pada kegiatan budidaya. Hal ini diduga sebagai akibat penggunaan induk dalam pemijahan yang kurang memadai secara genetika. Namun demikian, ikan hasil budidaya masih dapat digunakan dalam beberapa generasi lagi jika tidak dilakukan program perbaikan dengan meningkatkan keragaman genetik dari ikan stok jelawat yang ada. Nilai heterozigositas ikan jelawat budidaya 2006 lebih rendah sekitar 11\% dibandingkan ikan dari alam pada tahun 2008. Jika umumnya satu generasi ikan budidaya mengalami penurunan $10 \%$ maka sesungguhnya ikan jelawat yang ada dibudidaya sudah menurun sebanyak $2 x$-nya ( $22 \%$ dalam satu generasi ikan jelawat ( 3 tahun).

Secara statistik dengan menggunakan AMOVA (Analysis Molecular Variance) menunjukkan bahwa tidak terdapat perbedaan yang nyata secara genetik antara ikan jelawat hasil budidaya dan ikan rangkapan di alam $(P>0,05)$ berdasarkan fragmen dari dua primer (Tabel 1). Hal ini menunjukkan bahwa kemungkinan kedua stok ikan tersebut berasal dari nenek moyang populasi yang sama. Sehingga dalam penggunaanya dapat disatukan antar kedua stok yang ada, di samping untuk menaikkan variasi genetik ikan stok budidaya.

Keadaan ini akan terlihat lebih jelas pada hasil penghitungan jarak genetik berdasarkan fragmen dari dua primer. Jarak genetik yang dihitung menurut Nei (1972) tertera pada Tabel 1. Jarak genetik rata-rata antara stok ikan jelawat adalah sekitar 0,3381. Nilai jarak genetik pada ikan jelawat ini relatif lebih setara dibandingkan jarak genetik antara ikan dari populasi yang yang sama, seperti pada ikan kancra (Nugroho et al., 2006).

\section{KESIMPULAN}

Tidak terdapat perbedaan yang nyata secara genetik antar stok ikan jelawat dari budidaya (2006) dan hasil tangkapan alam di Sintang (2008). Keragaman tertinggi dimiliki ikan jelawat dari alam ras (heterozigositas $=$ $0,1450)$, kemudian ikan jelawat budidaya $(H=0,1305)$.

\section{SARAN}

Berdasarkan hasil pengujian DNA maka disarankan bahwa kedua stok ikan jelawat dapat dijadikan menjadi satu. Program seleksi dapat dipilih sebagai penghasil benih 
Tabel 1. Variasi genetik, uji Fst dan jarak genetik antar ikan jelawat hasil budidaya dan alam

\begin{tabular}{|c|c|c|}
\hline & Budidaya & Tangkapan alam (Sintang) \\
\hline & (2006) & (2008) \\
\hline Heterozigositas & 0.1305 & 0.145 \\
\hline $\begin{array}{l}\text { Uji FST antar ikan jelawat budidaya dan alam } \\
\text { Jarak genetik antar ikan jelawat budidaya dan alam (Nei, 1972) }\end{array}$ & \multicolumn{2}{|c|}{$\begin{array}{c}0.9465^{\text {ns }} \\
0.3381\end{array}$} \\
\hline
\end{tabular}

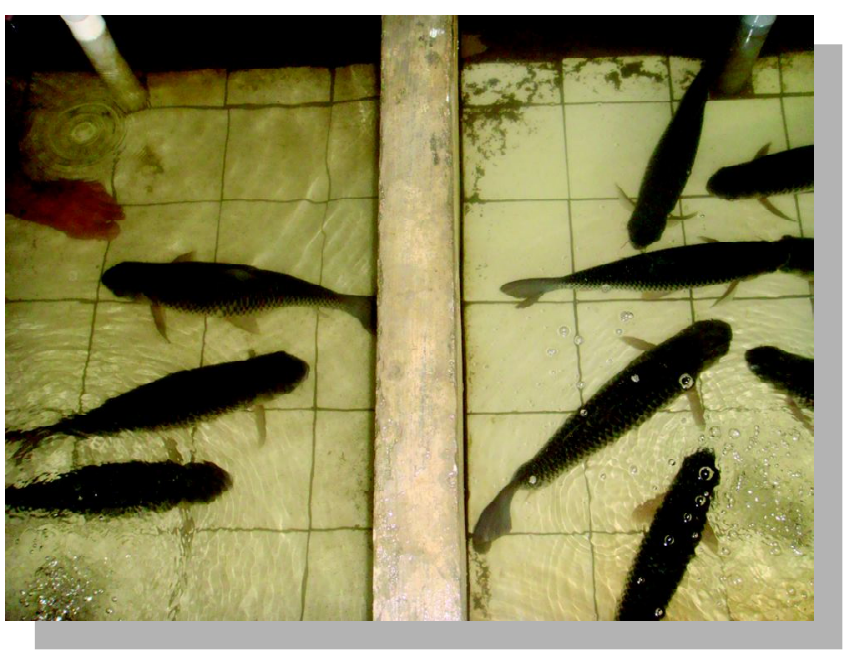

Gambar 2. Ikan jelawat dari budidaya (kiri) dan hasil tangkapan alam (kanan)

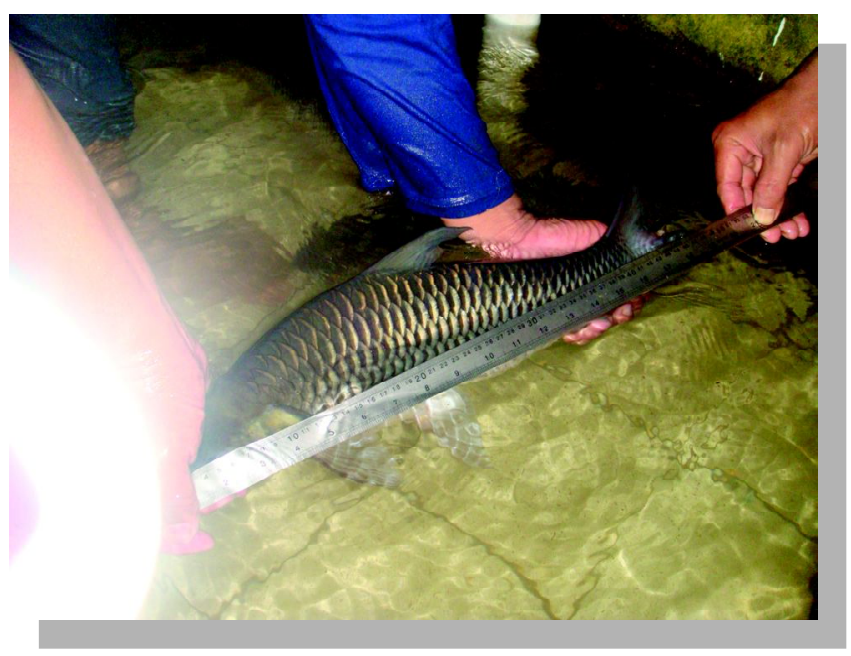

Gambar 4. Pengukuran panjang badan ikan jelawat

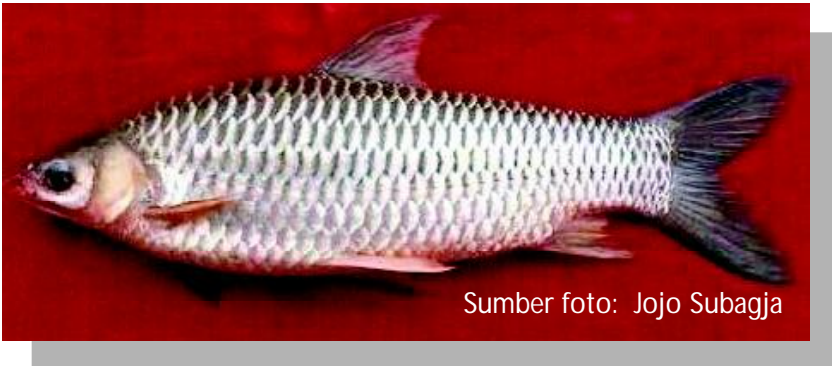

Gambar 3. Ikan jelawat

unggul. Program hibridisasi dapat dilakukan jika UPIS mempunyai stok jelawat yang berasal dari daerah lain yang berbeda dari stok yang ada sekarang (dengan asumsi genetik daerah lain juga berbeda).

\section{DAFTAR ACUAN}

Ferguson, A.J., Taggart, B., Prodohl, P.A., Mc. Meel, O., Thompson, C., Stone, C., McGinnity, P., \& Hynes, R.A. 1995. The application of molecular markers to the study and conservation of fish population, with special reference to Salmo. J. of Fish Biology, 47: 103126.

Miller, P.M. 1999. Tools for Population Genetic Analysis (TFPGA). Software.

Nugroho, E., Subagja, J., Asih, S., \& Kurniasih, T. 2006. Evaluasi keragaman genetik ikan kancra dengan menggunakan marker mtDNA D-loop dan Random Amplified Polymorphism DNA (RAPD). J. Ris. Akuakultur, 1(2): 211-217.

Nei, M. 1972. Genetic distance between populations. American Nature, 106: 283-292. 